\title{
The Effect of Free Cash Flow, Company Size, Profitability and Liquidity on Debt Policy for Manufacturing Companies Listed on IDX in 2016-2019 Periods
}

\author{
Adam Afiezan', Giovanni Wijaya ${ }^{2}$, Priscilia $^{3}$, Cindy Claudia ${ }^{4}$ \\ 1,2,3,4 Universitas Prima Indonesia Medan \\ giovanniiwijayaa77@gmail.com
}

\begin{abstract}
The purpose of this research is to analyze and study the effect of Free Cash Flow, Company Size, Profitability and Liquidity on the Debt Policy of manufacturing companies listed on the IDX in 2016-2019. This type of research is a quantitative descriptive one. Of the 169 populations, only 83 samples met the criteria. Data processing with multiple linear regressions. The partial test results are only liquidity that has a negative and significant effect on debt policy, while Free Cash Flow, Company Size and Profitability have no effect on debt policy. Simultaneous test results where Free Cash Flow, Company Size, Profitability and Liquidity have an influence on debt policy with the results of the determination coefficient of 0.589 which means as much as $58.9 \%$ of the variation in debt policy that can be explained by variables (FCF, company size, profitability and liquidity) where the remaining $41.1 \%$ is influenced by other factors.
\end{abstract}

Keywords

free cash flow, company size; profitability, liquidity, debt policy

\section{Introduction}

The debt policy is a policy to determine the funds of each company that comes from external sources. Managers in each company can pay attention to the risks of using debt in determining the proportion of debt appropriately in order to increase the value of the company. However, in fact there is disruption and inconsistency of debt policy resulting in a decrease in the value of the company so that the statement where the debt policy can increase the value of a company is not as expected.

One of the manufacturing companies, for example PT. Gunawan Dianjaya Steel, Tbk, whose use of debt continued to increase from 2016 to 2018 so that in 2018 the company suffered losses. But what is surprising is that in 2019 the use of debt jumped by $85 \%$, the company was able to increase its profit from the previous year which experienced a loss.

In the current economic development, manufacturing companies are required to be able to compete in the industrial world. Manufacturing companies need to invest to increase the company's business capital. To invest, various kinds of information about the issuer are needed, both company performance information in the form of financial statements or other relevant information. The economic development of a country can be measured in many ways, one of which is by knowing the level of world capital market development. (Angelia and Toni, 2020). The manufacturing industry plays a very important and strategic role in contributing Gross Domestic Product (GDP) to the national economy and labor absorption. This study is aimed atanalyzing factors influencing labor absorption of themanufacturing industry. (Pramusinto and Daerobi, 2020).

The fact of the misuse of debt can also be seen from a company that has been established since 1919, namely Nyonya Meneer having to accept the fact that the company was declared bankrupt because it failed to pay its debt to creditors amounting to 7 billion. 
From these events we can see that the analysis of the balance of use of debt is very important. There isThere are also various factors that affect the company's policy to take its debts, namely free cash flow, company size, profitability and liquidity.

Free cash flowis a depiction of cash flows in a company's financial statements for an accounting period. One healthy company has cash available for use in its debt policy, it can be seen from the amount of free cash flow that is in the company. Research by Ramadhani and Barus (2018) that the relationship between free cash flow and debt policy is significantly negative, while Oktariyani and Hasanah's research (2019) cannot prove that the effect of free cash flow is not significant on debt policy.

Large companies that have the flexibility and ability to obtain funds can certainly more easily access the capital market. Large companies have large assets, so creditors find it easier to obtain collateral. In carrying out company operations, management requires a lot of funds if the size of the company is getting bigger. Research by Ramadhani and Barus (2018) shows a significant positive result between company size with different debt policies with the results of research by Husna and Wahyudi (2016), namely that there is no effect of company size on debt policy.

The basic elements of the policy and the Occupational Safety and Health Management System consist of establishing policies, planning, implementing policies, measuring, evaluating performance, reviewing, and improving the implementation of an occupational safety and health management system on an ongoing basis by company management. (Marbun, 2020)

The use of small amounts of debt is called a profitable company because for operational purposes the company uses internal funds. According to agency theory, to reduce ignorance of the interests of shareholders in the misuse of funds by managers, it is possible to take advantage of debt for companies that have high profitability. The research results show that the relationship between profitability and debt policy is significantly positive by Esti, Fauziyanti and Hendrayanti (2019), while the research results show that profitability cannot affect debt policy by Ramadhani and Barus (2018).

We can measure liquidity, namely the ratio of current assets divided by current liabilities. A current asset ratio of $100 \%$ or more is owned by a company that has healthy liquidity. A liquid company means that the company has large funds to pay all of its obligations. The more liquid the company is, the more internal funds it will have to meet its operational needs. According to the pecking order theory, the source of funding is internal funds first (retained earnings), then issuance of new debt, and issuance of shares (Husnan, 2015: 286), so the company will use internal funds first as a source of corporate financing and not use external funds (debt ) estuti's research results.

The reference to previous research is from Silalahi's research (2018)In the food and beverage sub-sector, his research shows the influence of free cash flow on debt policy but there is no effect of profitability on debt policy. In this study, the researcher added other independent variables, namely company size and liquidity. In addition, multiple regression and classical assumptions made in previous studies used SPSS version 21, but in this study researchers used Eviews 9.

From research gap above, it can be concluded that the effect of free cash flow, company size, profitability and liquidity on debt policy has not been consistent with results from time to time, therefore researchers feel they still need to do further research in order to test the truth about "The Effect of Free Cash Flow, Company Size, Profitability and Liquidity on Debt Policy for Listed Manufacturing Companies on the IDX 2016-2019". 


\section{Review of Literatures}

\subsection{Theory of Influence Free Cash Flow against Debt Policy}

Oktariyani and Hasanah (2019: 25): A healthy company, one of which has cash available to be used in its debt policy, can be seen from the amount of free cash flow available to the company. Nasrizal, Kamaliah and Tika Rahmi Syafitri (2010): Companies add debt and issue new securities if there is less cash. According to Suryani and Khafid (2015: 23): Companies that do not survive a high increase in free cash flow, meaning that companies that are passive in utilizing free cash flow and lack of movement in the search for profitable projects, the amount of cash available and less use of debt.

\subsection{The Theory of the Effect of Company Size on Debt Policy}

According to Suryani and Khafid (2015: 24): The bigger the company will have a fast high growth rate so that the company can be more prepared to issue new shares and also increase loans, as well as the small size of the company can affect the capital structure. According to Mulyawan (2015: 247): The level of debt is getting bigger as a result of the bigger the size of the companyAccording to Sitanggang (2013: 76): The size of a company with large sales or market capitalists indicates the company's performance. The size of the company is easier to get access to sources of funds to get additional capital with debt.

\subsection{Influence Theory Profitability against Debt Policy}

Husna and Wahyudi (2016: 156): The Company has high profitability, so the company's debt policy is also low. Generally, companies with high profitability scales, using relatively small amounts of debt with a high return on investment, can be capitalized with retained earnings.

Riyanto (2013: 297): Companies that can meet their financial obligations as a result of the use of foreign capital must also have stable earnings. On the other hand, the company will bear the risk of not being able to pay interest expenses or not being able to pay various installments of the money during bad conditions, so it is certain to have unstable earnings.

According to Mulyawan (2015: 247) : Companies with low debt levels have a high level of profitability. This is explained by the pecking order theory which states that the level of profit is high, so the source of funds we receive will be even more abundant.

\subsection{The Theory of the Effect of Liquidity on Debt Policy}

According to Ramadhani and Barus (2018: 131): High company liquidity can increase the ability in terms of creditor confidence in the ability to assess the company to pay shortterm liabilities so that the company has high liquidity so that it is easier to obtain debt. Sunyoto (2018:14): Short-term loans, overdrafts and factoring can be borrowed from banks by companies if liquidity is insufficient.

According to Tampubolon (2013: 64): If there is financing of current assets by temporary corporations with long-term debt, the corporation will be excess debt when temporary financing is not needed. From this excess debt causes the corporation to pay interest on expenses that are not needed or the alternative to repay the debt will result in higher costsrelative expensive. 


\subsection{Conceptual Framework}

Researchers can create a conceptual framework based on the background and literature review as follows:

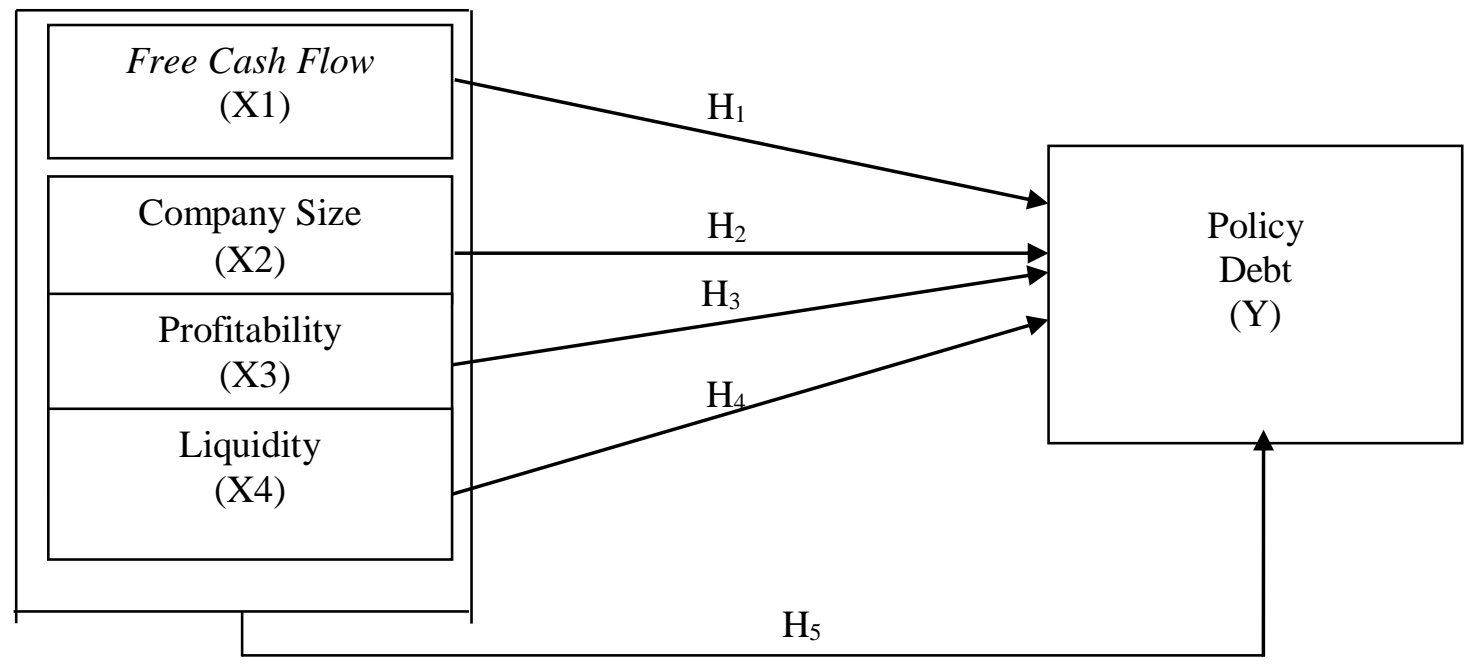

Figure 1. Conceptual Framework

\subsection{Hypothesis}

The following is the hypothesis of this research, namely:

H1 : Free Cash Flow Partially affect the debt policy of manufacturing companies listed on the IDX in 2016-2019.

H2 : Company size matters Partially on the debt policy of manufacturing companies listed on the IDX in 2016-2019.

H3 : Profitability has a partial effect on debt policy in manufacturing companies listed on the IDX in 2016-2019.

H4 : Liquidity has a partial effect on debt policy in manufacturing companies listed on the IDX in 2016-2019.

H5 : Free Cash Flow, Company size, profitability and liquidity partially influence the debt policy of manufacturing companies listed on the IDX in 2016-2019.

\section{Research Methods}

\subsection{Research Methods}

This research was conducted at manufacturing companies listed on the IDX through the official website www.idx.co.id. The research period was from February 2020 to December 2020. This type of research uses quantitative research, while the nature of the research is descriptive research.

Researchers used documentation data by recording, collecting and analyzing data on manufacturing companies listed on the IDX from 2016-2019. The type of data in this study uses secondary data. The population in this study was 169 . The technique of this research sample was based on purposive sampling.

According to Sugiyono (2017: 85): Purposive Samplingnamely the sampling technique carried out by determining certain considerations. The following are several criteria in selecting the sample in this study, which are as follows: 
1. Manufacturing companies listed on the IDX 2016-2019.

2. Manufacturing companies that publish complete financial reports for the period 2016 2019.

3. Manufacturing companies that experienced losses in the 2016-2019 period.

Table 1. Sample Table

\begin{tabular}{|c|l|c|}
\hline No. & \multicolumn{1}{|c|}{ Information } & Total \\
\hline 1. & Manufacturing companies are listed on the IDX 2016-2019 & 169 \\
\hline 2. & Manufacturing companies publish complete financial reports for 2016-2019 & $(37)$ \\
\hline 3. & Manufacturing companies experienced losses for the period 2016-2019 & $(49)$ \\
\hline & Number of samples & $\mathbf{8 3}$ \\
\hline
\end{tabular}

Source: www.idx.co.id

The number of samples that can be used in this study is 83 companies. The number of periods in this study was 4 years, then the number of observations was 332 data.

\subsection{Identification and Operational Definition of Research Variables}

The operational definition is a selected variable interpretation. The variables used in this study consisted of 4 independent variables, namely Free Cash Flow (X1), Company Size (X2), Profitability (X3) and Liquidity (X4) while the dependent variable used was Debt Policy (Y). For more details, the identification and operational definition of each variable can be seen in the table below:

Table 2. Operational Definition and Variable Measurement

\begin{tabular}{|c|c|c|c|}
\hline Variable & Concept & Indicator & Scale \\
\hline $\begin{array}{l}\text { Free Cash } \\
\quad \text { Flow } \\
\quad \text { (X1) }\end{array}$ & $\begin{array}{l}\text { Calculation of the flow of cash and } \\
\text { cash equivalents from investing, } \\
\text { operating and financing company } \\
\text { activities } \\
\text { Source: Utari (2014: } 13)\end{array}$ & $\begin{array}{l}\text { End-of-year cash flow for the } \\
2016-2019 \text { period of } \\
\text { manufacturing companies } \\
\text { Source: Subramanyam and } \\
\text { Wild (2011:91) }\end{array}$ & Ratio \\
\hline $\begin{array}{l}\text { Company } \\
\text { Size } \\
\text { (X2) }\end{array}$ & $\begin{array}{l}\text { To find out the size of a company, } \\
\text { investors observe the large scale of the } \\
\text { company } \\
\text { Source: Sunyoto }(2013: 6)\end{array}$ & $\begin{array}{l}\text { Natural Asset Logarithm } \\
\text { Source: Rodoni (2014: 193) }\end{array}$ & Ratio \\
\hline $\begin{array}{c}\text { Profitabilit } \\
\text { y } \\
(\mathrm{X} 3)\end{array}$ & $\begin{array}{l}\text { Describes the company's ability to } \\
\text { increase profits } \\
\text { Source: Murhadi (2015: 63) }\end{array}$ & $\begin{array}{l}\text { ROA = Earning After Taxes } \\
\text { Total Assets } \\
\text { Source: Sudana (2011: 22) }\end{array}$ & Ratio \\
\hline $\begin{array}{l}\text { Liquidity } \\
\text { (X4) }\end{array}$ & $\begin{array}{l}\text { To measure the ability of a company } \\
\text { to meet obligations or pay off short- } \\
\text { term debt that is due on time or when } \\
\text { it is collected. } \\
\text { Source: Purwanti }(2017: 257)\end{array}$ & $\begin{array}{l}\text { Current Ratio= Current assets } \\
\text { Short liability } \\
\text { Source: Hery (2015: } 180)\end{array}$ & \\
\hline $\begin{array}{l}\text { Debt } \\
\text { policy } \\
(Y)\end{array}$ & $\begin{array}{l}\text { The ability of company management } \\
\text { in order to obtain sources of funds can } \\
\text { be used to finance all operational } \\
\text { activities of the company } \\
\text { Source: Riyanto (2014: } 98)\end{array}$ & $\begin{array}{l}\text { DER = Total Debt } \\
\text { Capital (Equity) } \\
\text { Source: Harahap (2013: 303) }\end{array}$ & Ratio \\
\hline
\end{tabular}




\subsection{Classic Assumption Test}

The classic assumption test is a test conducted to measure whether the regression estimation results carried out in this research are completely free of multicollinearity indications, heteroscedasticity indications and autocorrelation indications. The requirements for the classic assumption test must be met with the regression model with BLUE requirements (best linear unbiased estimator), which is normally distributed, without any heteroscedasticity, without multicollinearity, and without autocorrelation. The classical assumption test in this study is divided into 4 test tools, namely the normality test, multicollinearity test, heteroscedasticity test and autocorrelation test.

\subsection{Research Model}

Hypothesis testing in this study is to examine whether the independent variable has a partial or simultaneous effect on the dependent variable using the $F$ test and test. The regression model used is multiple regression model analysis with the formula:

$$
\mathrm{Y}=\mathrm{a}+\mathrm{b} 1 \mathrm{X} 1+\mathrm{b} 2 \mathrm{X} 2+\mathrm{b} 3 \mathrm{X} 3+\mathrm{b} 4 \mathrm{X} 4+\mathrm{e}
$$

Where:

\begin{tabular}{|c|c|}
\hline$Y$ & $=$ Debt policy \\
\hline$a$ & $=$ Constant \\
\hline $1 \mathrm{~b} 2 \mathrm{~b} 3 \mathrm{~b}$ & $=$ Regression coefficient \\
\hline $\mathrm{X} 1$ & $=$ FCF $($ Free Cash Flow $)$ \\
\hline 2 & $=$ Company Size \\
\hline 3 & $=$ Profitability \\
\hline & $=$ Liquidity \\
\hline & $=$ Confounding variables \\
\hline
\end{tabular}

\section{Result and Discussion}

\subsection{Descriptive Statistics}

The total data studied were 332 data which can be obtained from 83 companies $\mathrm{x} 4$ years of the study period. In the following, we can see an overview of the minimum, maximum, mean and standard deviation of each tested variable.

Table 3. Descriptive Statistics

Descriptive Statistics

\begin{tabular}{|l|c|r|r|r|r|}
\hline & $\mathrm{N}$ & \multicolumn{1}{|c|}{ Minimum } & \multicolumn{1}{c|}{ Maximum } & \multicolumn{1}{c|}{ Mean } & \multicolumn{1}{c|}{ Std. Deviation } \\
\hline FCF & 332 & -126576603862 & 31574000000000 & 1583718753295 & 4037519729199,6 \\
UkuranPerusahaan & 332 & 25,216 & 33,495 & 28,84513 & 1,607957 \\
Profitabilitas & 332 &, 000 &, 921 &, 08022 &, 100338 \\
Likuiditas & 332 &, 113 & 21,705 & 2,67638 & 2,393646 \\
KebijakanHutang & 332 & $-2,215$ & 5,443 &, 91395 &, 863800 \\
Valid N (listwise) & 332 & & & & \\
\hline
\end{tabular}

Free Cash Flow has a minimum value of -Rp 126,576,603,862, - which is obtained by PT. Sekar Laut, Tbk in 2018 and a maximum value of Rp. 31,574,000,000,000, - which was obtained by PT. Astra International, Tbk in 2017. The average value of manufacturing Free Cash Flow is IDR 1,583,718,752,395. 
The size of the company has a minimum value of 25,216 which is obtained by PT. Primarindo Asia Infrastructure, Tbk in 2017 and a maximum value of 33.495 obtained by PT. Astra International, Tbk in 2019. The average value is 28,84513 .

Profitability has a minimum value of 0,000 which is obtained by PT. Star Petrochem, Tbk in 2018 and a maximum value of 0.921 obtained by PT. Merck, Tbk in 2018. The average score is 0.08022 .

Liquidity has a minimum value of 0.113 which is obtained by PT. Astra International, Tbk in 2018 and a maximum value of 21,705 obtained by PT. Duta Pertiwi Nusantara, Tbk in 2019. The average score was 2.67638 .

The debt policy has a min value of $-2,215$, namely at PT. Primarindo Asia Infrastructure, Tbk in 2018 with a max value of 5.443 at PT. Alaska Industrindo, Tbk in 2018 and the average value is 0.91395 .

\subsection{Classic Assumption Test}

\section{a. Normality Test}

The data in the study did not meet the normality assumption so that 26 data containing outliers> 3 would be discarded and then the data was transformed using the LN technique. The following results of the normality test of this study are as follows:

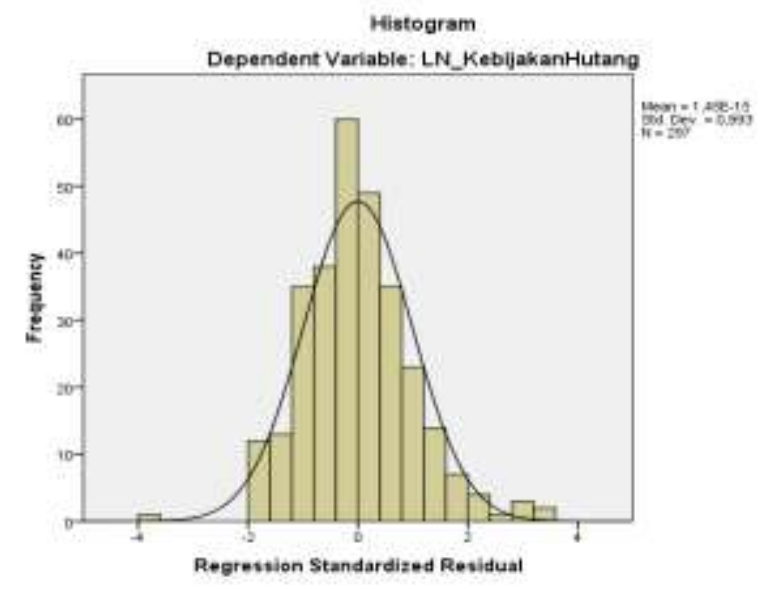

Figure 2. Histogram Graph

From the graph the histogram shows that after the transformation the data has a normal distribution because the visual graph is symmetrical following the bell-shaped direction and without going left to right. In addition to the normality assumption histogram, it can also be seen from the P-Plot normality graph.

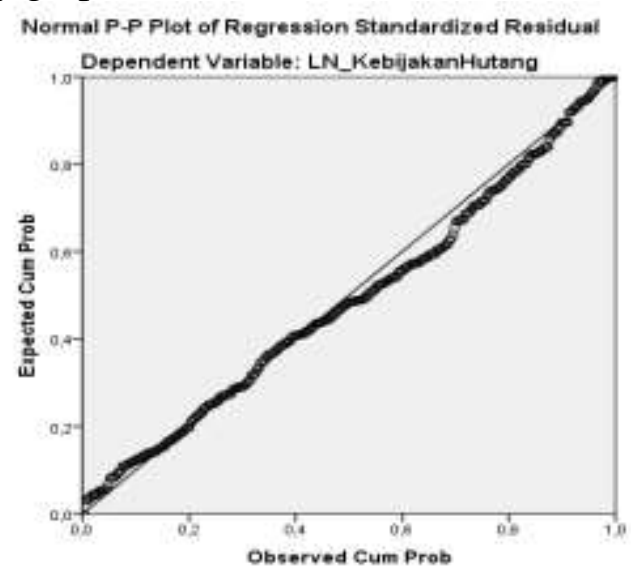

Figure 3. P-P Plot Graph 
From the P Plot graph test shows the data has a normal distribution which can be seen from the plot that moves along the diagonal line.

Table 4. KS Test Results

One-Sample Kolmogorov-Smirnov Test

\begin{tabular}{|ll|r|}
\hline & & $\begin{array}{r}\text { Unstandardiz } \\
\text { ed Residual }\end{array}$ \\
\hline N & Mean & 297 \\
Normal Parameters & a,b &, 0000000 \\
& Std. Deviation &, 51816430 \\
& Absolute &, 069 \\
Kolmogorov-Smirnov Z & Positive &, 069 \\
Asymp. Sig. (2-tailed) & &,- 033 \\
& & 1,190 \\
\end{tabular}

a. Test distribution is Normal.

b. Calculated from data.

There is a K-S test result that has a significant value of $0.118>0.05$ so that it can be concluded that the data after being transformed has met the requirements of the normality assumption.

\section{b. Multicollinearity Test}

The multicollinearity test is the second assumption requirement after normality. To find out whether the independent variables have no correlation, the tolerance / resistance and VIF values can be seen.

Table 5. Multicollinearity Test

Coefficients $^{\mathrm{a}}$

\begin{tabular}{|ll|r|r|}
\hline \multirow{2}{*}{ Model } & \multicolumn{2}{|c|}{ Collinearity Statistics } \\
\cline { 3 - 4 } & & Tolerance & \multicolumn{1}{c|}{ VIF } \\
\hline 1 & LN_FCF &, 186 & 5,382 \\
& LN_UkuranPerusahaan &, 194 & 5,146 \\
& LN_Profitabilitas &, 771 & 1,297 \\
& LN_Likuiditas &, 630 & 1,588 \\
\hline
\end{tabular}

a. Dependent Variable: LN_KebijakanHutang

Based on the results of the multicollinearity test, it shows that the independent variables are not correlated because each independent variable has a resistance value or a tolerance value greater than 0.10 and the VIF deviation value of each independent variable data is less than $<10$.

\section{c. Autocorrelation Test}

The autocorrelation test is a test to assess whether the linear regression model has a correlation or not between the sample at time $t$ and the sample at $t-1$ (previously). The condition of this test is that there is no autocorrelation where Asymp. Sig. (2-tailed) is greater than 0.05. If Asymp. Sig. (2-tailed) is smaller than 0.05, then there is autocorrelation, here are the test results: 
Table 6. Autocorrelation Test

Runs Test

\begin{tabular}{|l|r|}
\hline & $\begin{array}{c}\text { Unstandardiz } \\
\text { ed Residual }\end{array}$ \\
\hline Test Value $^{\text {a }}$ &,- 02168 \\
Cases < Test Value & 148 \\
Cases >= Test Value & 149 \\
Total Cases & 297 \\
Number of Runs & 137 \\
Z & $-1,453$ \\
Asymp. Sig. (2-tailed) &, 146 \\
\hline
\end{tabular}

a. Median

From the test results, it can be seen that the significant value obtained is $0.146>0.05$ so that this test can be concluded that there is no autocorrelation.

\section{d. Heteroscedasticity Test}

Heteroscedasticity test, namely testing the regression model whether there is an inequality or similarity of variants from one observation disturbing factor to another for each independent variable. This test uses graphical and statistical methods, where the statistical method chosen is Spearman's rho test.

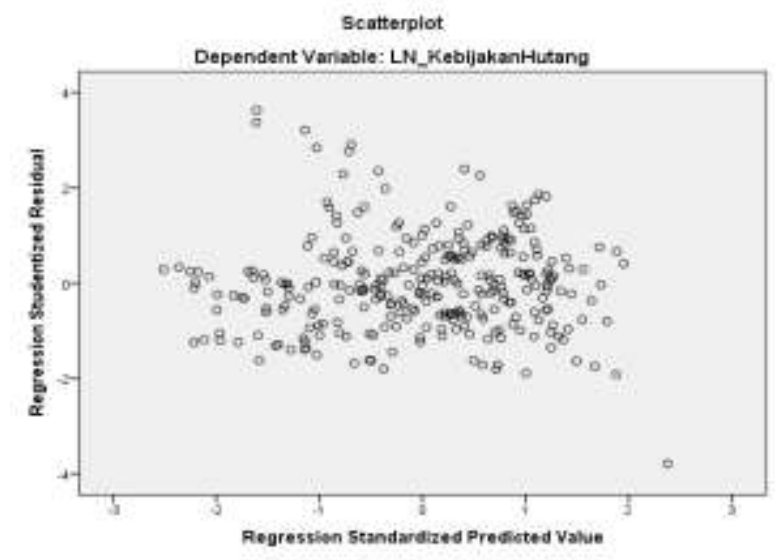

Figure 3. Scatterplot Heteroscedasticity Test

From the results of the scatterplot graph test the data shows that the plots have been scattered randomly so that the research data has met the requirements of the classical assumption test because there is no heteroscedasticity.

Table 7. Spearman's rho test

\begin{tabular}{|c|c|c|c|c|c|c|c|}
\hline \multicolumn{8}{|c|}{ Correlations } \\
\hline & & & LN_FCF & $\begin{array}{c}\text { LN_UkuranPe } \\
\text { rusahaan }\end{array}$ & $\begin{array}{c}\text { LN_Profitabilit } \\
\text { as }\end{array}$ & LN_Likuiditas & $\begin{array}{l}\text { Unstandardiz } \\
\text { ed Residual }\end{array}$ \\
\hline \multirow{15}{*}{$\begin{array}{l}\text { Spearma } \\
\text { n's rho }\end{array}$} & \multirow[t]{3}{*}{ LN_FCF } & Correlation Coefficient & 1,000 & $830^{1 \pi}$ & $373^{\text {nt }}$ & $218^{n \pi}$ &,- 044 \\
\hline & & sig. (2-tailed) & &, 000 &, 000 &, 000 & 445 \\
\hline & & N & 301 & 301 & 300 & 301 & 297 \\
\hline & \multirow{3}{*}{$\begin{array}{l}\text { LN_Ukuran } \\
\text { Perusahaan }\end{array}$} & Correlation Coefficient & $830^{2 \pi}$ & 1,000 & $.216^{N 1}$ &,- 088 &,- 042 \\
\hline & & sig. (2-tailed) &, 000 & &, 000 & 126 &, 468 \\
\hline & & N & 301 & 306 & 305 & 306 & 297 \\
\hline & \multirow{3}{*}{$\begin{array}{l}\text { LN_Profitabi } \\
\text { litas }\end{array}$} & Correlation Coefficient & $.373^{n \pi}$ & $216^{2 \pi}$ & 1,000 & $375^{\pi n}$ &,- 074 \\
\hline & & sig. (2-tailed) &, 000 &, 000 & & 000 & 206 \\
\hline & & N & 300 & 305 & 305 & 305 & 297 \\
\hline & \multirow{3}{*}{$\begin{array}{l}\text { LN_Likuidita } \\
\mathrm{s}\end{array}$} & Correlation Coefficient & $218^{n \pi}$ &,- 088 &, $375^{\prime \prime}$ & 1,000 &,- 088 \\
\hline & & sig. (2-tailed) &, 000 & 126 & 000 & & 131 \\
\hline & & N & 301 & 306 & 305 & 306 & 297 \\
\hline & \multirow{3}{*}{$\begin{array}{l}\text { Unstandardi } \\
\text { zed } \\
\text { Residual }\end{array}$} & Correlation Coefficient &,- 044 &,- 042 &,- 074 &,- 088 & 1,000 \\
\hline & & Sig. (2-tailed) & 445 & 468 & 206 & 131 & \\
\hline & & $N$ & 297 & 297 & 297 & 297 & 297 \\
\hline
\end{tabular}

**, Correlation is significant at the 0.01 level (2-tailed) 
From the results of this test, it shows that heteroscedasticity does not occur because the significant value of the four independent variables (Free Cash Flow, company size, profitability and liquidity) is greater than the specified significant value limit, which is $>0.05$.

\subsection{Multiple Linear Regression Analysis}

Table 8. Equations for Multiple Linear Regression Analysis

Coefficients $^{a}$

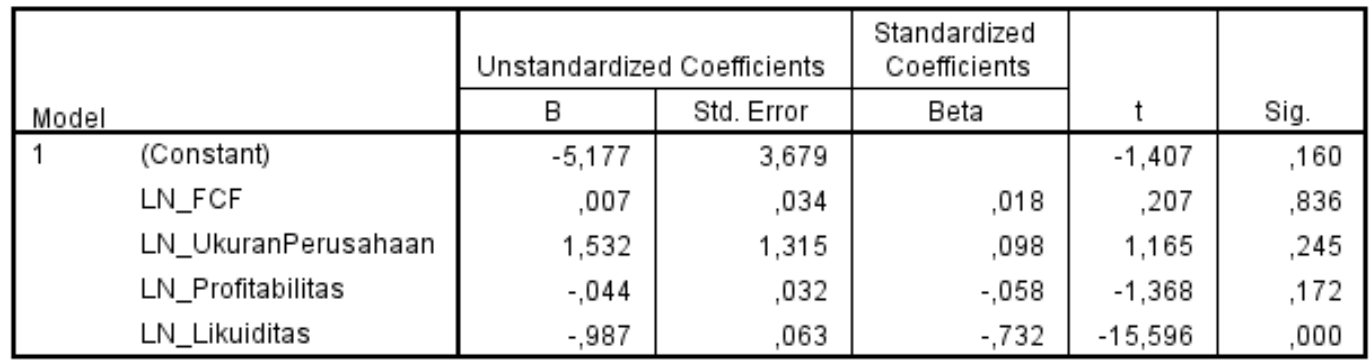

a. Dependent Variable: LN_KebijakanHutang

The multiple regression equation in this study is:

Debt policy $=-5.177+0.007$ Free Cash Flow +1.532 Firm Size -0.044 Profitability -0.987 Liquidity

From the multiple regression model equation, it can be explained as follows:

1. The constant (a) of -5,177 means that if the independent variables (Free Cash Flow, company size, profitability and liquidity) are constant or have a value of 0 , the debt policy will be worth $-5,177$ units.

2. b1X1 of 0.007 means that each 1 unit increase in Free Cash Flow will cause an increase in debt policy of 0.007 units.

3. b2X2 of 1.532 means that every 1 unit increase in company size will lead to an increase in debt policy of 1.532 units.

4. b3X3 of -0.044 means that every 1 unit increase in Profitability will cause a decrease in debt policy of 0.044 units.

5. b4X4 of $-0,987$ means that every 1 unit increase in liquidity will cause a decrease in the debt policy of 0.987 units.

\subsection{Coefficient of Determination}

Table 9. Determination Coefficient Test

Model Summary

\begin{tabular}{l|c|c|c|c|}
\hline Model & $\mathrm{R}$ & R Square & $\begin{array}{c}\text { Adjusted R } \\
\text { Square }\end{array}$ & $\begin{array}{c}\text { Std. Error of } \\
\text { the Estimate }\end{array}$ \\
\hline 1 &, $771^{\text {a }}$ &, 594 &, 589 &, 52170 \\
\hline
\end{tabular}
a. Predictors: (Constant), LN_Likuiditas,
LN_UkuranPerusahaan, LN_Profitabilitas, LN_FCF

The magnitude of the influence of the independent variable on the dependent variable is seen from the Adjusted R Square value of 0.589 which means $58.9 \%$ of the variation in debt policy which can be explained by the Free Cash Flow variable, company size, profitability and liquidity) where the rest is $41.1 \%$ influenced by other factors such as good corporate governance variables, taxes and others. 
Table 10. F test

ANOVA $^{\mathrm{a}}$

\begin{tabular}{|ll|r|r|r|r|r|}
\hline Model & & \multicolumn{1}{c|}{$\begin{array}{c}\text { Sum of } \\
\text { Squares }\end{array}$} & df & Mean Square & \multicolumn{1}{c|}{ F } & Sig. \\
\hline 1 & Regression & 116,469 & 4 & 29,117 & 106,981 &, $000^{\mathrm{b}}$ \\
& Residual & 79,474 & 292 &, 272 & & \\
& Total & 195,943 & 296 & & & \\
\hline
\end{tabular}

a. Dependent Variable: LN_KebijakanHutang

b. Predictors: (Constant), LN_Likuiditas, LN_UkuranPerusahaan, LN_Profitabilitas, LN_FCF

The value of the $\mathrm{F}$ table for $\mathrm{df} 1=4$ and $\mathrm{df} 2=292$, which is 2.40 . By looking at the results of the $\mathrm{F}$ test, it is obtained that the value of $\mathrm{F}$ calculated $(106,981)>\mathrm{F}$ table 2.40 and a significant value of $0,000<0.05, \mathrm{Ha}$ is simultaneously accepted by the four variables (Free Cash Flow, company size, profitability and liquidity) have a significant effect on debt policy. Manufacturing companies listed on the IDX in 2016-2019.

\subsection{T Test}

Table 11. $t$ test

Coefficients $^{a}$

\begin{tabular}{|c|c|c|c|c|c|c|}
\hline \multirow{2}{*}{\multicolumn{2}{|c|}{ Model }} & \multicolumn{2}{|c|}{ Unstandardized Coefficients } & \multirow{2}{*}{$\begin{array}{c}\text { Standardized } \\
\text { Coefficients } \\
\text { Beta } \\
\end{array}$} & \multirow[b]{2}{*}{$\mathrm{t}$} & \multirow[b]{2}{*}{ Sig. } \\
\hline & & $\mathrm{B}$ & Std. Error & & & \\
\hline \multirow[t]{5}{*}{1} & (Constant) & $-5,177$ & 3,679 & & $-1,407$ & .160 \\
\hline & LN_FCF &, 007 &, 034 & ,018 & 207 &, 836 \\
\hline & LN_UkuranPerusahaan & 1,532 & 1,315 & ,098 & 1,165 & 245 \\
\hline & LN_Profitabilitas &,- 044 &, 032 &,- 058 & $-1,368$ & .172 \\
\hline & LN_Likuiditas &,- 987 &, 063 &,- 732 & $-15,596$ &, 000 \\
\hline
\end{tabular}

a. Dependent Variable: LN_KebijakanHutang

The amount of t table at alpha 0.05 (two tailed), df 292 is 1.968 . By comparing the test results partially with the size of the table:

1. The X1 variable in this study, namely free cash flow, has no effect on the debt policy on manufacturing companies listed on the IDX in 2016-2019 because value tcount $(0.207)$ $<$ ttable $(1,968)$ and a significant value of $0.836>0.05$.

2. The variable $X 2$ in this study is the size of the company has no effect on the debt policy on manufacturing companies listed on the IDX in 2016-2019 because value tcount (1.165) $<$ ttable $(1,968)$ and a significant value of $0.245>0.05$.

3. The X3 variable in this study, namely profitability, has no effect on debt policy manufacturing companies listed on the IDX in 2016-2019 because the value -thitung ($1,368)>-t$ tabel $(-1,968)$ and a significant value of $0.172>0.05$.

4. The X4 variable in this study, namely liquidity, has a negative and significant effect on debt policy on manufacturing companies listed on the IDX in 2016-2019 because -thitung value $(-15,596)<-$ ttabel $(-1,968)$ and a significant value of $0.000<0.05$. 


\subsection{Effects of X1 against $Y$}

The results of the study cannot prove the effect of FCF against debt policy. The results of previous research by Oktariyani and Hasanah (2019) also show that the FCF variable has no influence on debt policy. This is because the company focuses more on the interest of utilizing FCF funds for investment and operational purposes rather than increasing its debt.

\subsection{Influence X2 against Y}

The results of the study cannot prove the effect of company size against debt policy. The results of previous research by Husna and Wahyudi (2016) also show that there is no effect of company size on debt policy. The size of the company cannot be used as a measuring tool in determining the level of debt / debt policy to be pursued because large companies do not necessarily like high debt, and small companies also do not necessarily have low debt.

\subsection{Effects of $\mathrm{X} 3$ against $Y$}

The research results cannot prove influence Profitability against debt policy. The results of previous research by Ramadhani and Barus (2018) also show that there is no effect of profitability on debt policy. This is because the non-productive company assets result in the net profit earned on the total assets owned by the company not being used for long-term investment but only for the company's operational activities, namely sales.

\subsection{Effect of X4 on Y}

The results of this study prove the effect of liquidity on debt policy. The results of previous research by Estuti et al (2019) showthe relationship between liquidity and debt policy is significant and negative. This is because companies with a high level of liquidity are more likely to reduce the use of their debt.

\section{Conclusion}

The conclusions from the results of this study are:

1. Free Cash Flow does not affect the debt policy of manufacturing companies listed on the IDX in 2016-2019 which can be seen from the value tcount $0.207<$ ttable 1,968 and significant $0.836>0.05$.

2. The size of the company does not affect the debt policy of manufacturing companies listed on the IDX in 2016-2019 which can be seen from the value tcount $1.165<$ ttable 1,968 and a significant value of $0.245>0.05$.

3. Profitability does not affect the debt policies of manufacturing companies listed on the IDX in 2016-2019 which can be seen from -thitung value -1,368>-ttabel -1,968 and a significant value of $0.172>0.05$

4. Liquidity as measured by the Current Ratio negatively and significantly affects the debt policy of manufacturing companies listed on the IDX 2016-2019. -count -15,596<-ttabel 1,968 and a significant value of $0.000<0.05$.

5. Simultaneously, the four independent variables influence debt policy manufacturing companies listed on the IDX in 2016-2019.

6. The magnitude of the influence of the variation of the independent variables on the dependent variable is seen from the adjusted $\mathrm{R}$ Square value on the coefficient of determination with the magnitude of the influence of $58.9 \%$ where the remaining $41.1 \%$ is influenced by other variables. 
Researchers provide suggestions for interested parties, namely:

1. For further research it is recommended to use another sector if you want to continue research with the same variables because there is only one variable that is significant to debt policy.

2. For investors who want to invest in manufacturing companies, it is very important to analyze the level of a company's debt policy, where it is known that in the manufacturing sector many companies are not able to manage their debts properly so they go bankrupt.

3. For the manufacturing sector, it is advisable to be more careful when using debt because it is often not balanced with sales and making a profit that makes the company experience financial difficulties.

\section{References}

Angelia, N and Toni, N. (2020). The Analysis of Factors Affecting Dividend Policy in Food and Beverage Sector Manufacturing Companies Listed in Indonesia Stock Exchange in 2015-2017. Budapest International Research and Critics Institute-Journal (BIRCIJournal). P. 902-910.

Estuti, EP, Fauziyanti, W., \& Hendrayanti, S. (2019). The Effect of Liquidity, Profitability and Dividend Policy on Company Debt Policy (Empirical Study of Manufacturing Companies Listed on the Indonesia Stock Exchange 2013-2017). In Proceedings of the Unimus National Seminar (Vol. 2).

Hery. (2015). Financial Statement Analysis. Jakarta: Earth Literacy.

Husna, R. (2016). The Influence of Company Size, Profitability and Business Risk on Debt Policy. Neo-Bis, 10 (2), 155-177.

Kamaliah, N., \& Syafitri, TR (2010). Analysis of the effect of free cash flow, dividend policy, managerial share ownership, and institutional share ownership on debt policy. Journal of Economics, University of Riau.

Marbun, J. (2020). Juridical Analysis of the Occupational Safety and Health Management System in the Company. Budapest International Research and Critics Institute-Journal (BIRCI-Journal). P. 895-901

Mulyawan, Setia. (2015). Financial Management. Bandung: CV. Faithful Library.

Murhadi, Werner R. (2015). Financial Statement Analysis: Projection and Valuation of Shares. Jakarta: Publisher Salemba Empat.

Oktariyani, O., \& Hasanah, A. (2019). The Effect of Free Cash Flow, Liquidity and Foreign Ownership on Debt Policy in Companies Listed on the Indonesia Stock Exchange. Journal of Applied Managerial Accounting, 3 (1), 20-35.

Purwanti, M. (2017). Effect of Liquidity, Profitability and Sales Growth on debt policy (Empirical Study of Food and Beverage Companies Listed on the IDX). e-Journal of Business Administration, 5 (2), 255-268.

Pramusinto, N. and Daerobi, A. (220). Labor Absorption of the Manufacturing Industry Sector in Indonesia. Budapest International Research and Critics Institute-Journal (BIRCI-Journal). p. 549-561

Ramadhani, S., \& Barus, AC (2018). Debt Policy for Main Sector Companies Listed on the Indonesia Stock Exchange for the period 2013-2016. Journal of Micro-Civil Economics Entrepreneurs: JWEM, 8 (2), 127-138.

Silalahi, SM, Siahaan, Y., Susanti, E., \& Supitriyani, S. (2018). The Effect of Free Cash Flow and Profitability on Debt Policy in Food and Beverage Sub-Sector Companies Listed on the Indonesia Stock Exchange. Financial: Journal of Accounting, 4 (2), 62-69. 
Sitanggang, JP. (2013). Advanced Corporate Financial Management. Jakarta: Mitra Wacana Media.

Sudana, I Made. (2015). Corporate Financial Management: Theory \& Practice. Jakarta: Erlangga Publisher.

Sunyoto, Danang. (2013). Accounting Research Methods. Bandung: PT. Refika Aditama.

Suryani, AD, \& Khafid, M. (2015). Effect of Free Cash Flow, Company Growth, Dividend Policy and Company Size on Debt Policy. Essay. Department of Accounting, State University of Semarang.

Utari, Dewi, et al. (2014). Financial Management. Jakarta: Mitra Wacana Media.

Winna, HT (2019). The Effect of Profitability, Liquidity and Debt Policy on Dividend Policy in Manufacturing Companies. Journal of Accounting Paradigm, 1 (2), 523-532. 